\title{
ROCK1 Gene
}

National Cancer Institute

\section{Source}

National Cancer Institute. ROCK1 Gene. NCI Thesaurus. Code C24744.

This gene is involved in the regulation of cell division, cytoskeletal remodeling and smooth muscle contraction. 